\title{
Sosialisasi dan Pelatihan Pangan Organik Bagi Masyarakat Desa Sambirejo, Kecamatan Pare, Kabupaten Kediri, Jawa Timur
}

\author{
Ig. Jaka Mulyana \\ Universitas Katolik Widya Mandala \\ Surabaya
}

\author{
Lusia Permata Sari Hartanti \\ Universitas Katolik Widya Mandala \\ Surabaya
}

\author{
Dian Trihastuti \\ Universitas Katolik Widya Mandala \\ Surabaya
}

Ivan Gunawan

Universitas Katolik Widya Mandala Surabaya

\begin{abstract}
The application of various technologies to improve the quality of agricultural intensification generally focuses on the use of high-quality seeds. However, this method requires the usage of chemical fertilizers, thus making farmers dependent on chemical fertilizers. This is contrary to the concept of organic farming, which emphasizes the application of management practices that prioritize the use of inputs from the waste of cultivation activities on the land, and considers the adaptability to local conditions. In line with the government program called "2010 GO ORGANIC", which has the objective to empower organic farmers, Gubug Lazaris is motivated to empower the community through socialization and training with the topic in organic farming. The initial survey was conducted to identify the needs and problems faced by the community. The results of this survey were used to prepare and develop training materials. The socialization and training were attended by 50 participants, most of whom were residents of Sambirejo village. At the end of the activity, a survey was carried out to find out the responses from the participants. The results show that 57.5\% of participants are very interested in consuming organic food and $42.5 \%$ of participants are interested in growing organic plants. From the discussion during the training, it is found that the challenges of organic farming are public awareness of the importance of healthy living and environmental sustainability. Another challenge is the price of organic food, which is relatively more expensive than nonorganic food.
\end{abstract}

Keywords: Community empowerment; Organic farming; Training

\begin{abstract}
Abstrak
Penerapan berbagai teknologi dalam upaya peningkatan mutu intensifikasi pertanian secara umum fokus pada penggunaan benih unggul yang bermutu. Namun, penggunaan benih unggul bermutu menuntut penggunaan pupuk kimia sehingga menjadikan petani tergantung pada pupuk kimia. Hal ini bertentangan dengan konsep pertanian organik yang menekankan penerapan praktik-praktik manajemen yang lebih mengutamakan penggunaan input dari limbah kegiatan budidaya di lahan, serta mempertimbangkan daya adaptasi terhadap kondisi setempat. Sejalan dengan program pemerintah GO ORGANIK 2010 untuk memberdayakan petani organik, Gubug Lazaris termotivasi untuk memberdayakan masyarakat sekitar melalui kegiatan sosialisasi dan pelatihan di bidang pertanian organik. Survei awal dilakukan untuk identifikasi kebutuhan dan permasalahan yang dihadapi oleh masyarakat. Hasil survei ini digunakan untuk mempersiapkan dan menyusun materi sosialisasi dan pelatihan. Pelaksanaan sosialisasi dan pelatihan dihadiri oleh 50 peserta yang sebagian besar merupakan warga desa Sambirejo. Pada akhir kegiatan dilakukan penyebaran senerai untuk mengetahui respon dari peserta. Hasil senerai menunjukkan bahwa 57,5\% peserta sangat tertarik mengonsumsi pangan organik dan 42,5\% peserta tertarik menanam tanaman organik. Dari diskusi selama kegiatan diperoleh informasi bahwa tantangan pertanian organik ini terutama penyadaran masyarakat akan pentingnya hidup sehat dan kelestarian lingkungan. Tantangan yang lain adalah harga pangan organik yang relatif lebih mahal.
\end{abstract}

Kata kunci: Pelatihan; Pemberdayaan masyarakat; Pertanian organik. 


\section{Pendahuluan}

Dengan berkembangnya penerapan berbagai teknologi dalam upaya peningkatan mutu intensifikasi pertanian khususnya penggunaan benih unggul bermutu, banyak masalah yang timbul dibalik semua kelebihannya. Salah satunya adalah dengan penggunaan benih unggul bermutu yang menuntut penggunaan pupuk kimia menjadi prioritas petani sehingga menjadikan petani tergantung pada pupuk kimia, hal ini terlihat dari dosis pemupukan yang cenderung terus meningkat bahkan melebihi dosis yang telah dianjurkan. Semakin intensif suatu pertanian, maka akan memacu pemberian bahan kimia ke dalam tanah melalui pemupukan buatan dan pemberian pestisida secara terus-menerus, yang tentunya akan mengancam kesehatan tanah, tanpa ada upaya pengembalian zat hara di dalam tanah yang menyebabkan tanah pertanian semakin lama semakin kurus dan sakit. Walaupun jenis dan dosis pupuk kimia ditingkatkan namun karena tanah telah sakit dan bergantung pada pupuk kimia, produksi tidak bisa maksimal kemlai malah cenderung menurun. Hal ini kalau dibiarkan secara terus-menerus akan mengancam kelestarian lingkungan hidup di sekitar kita. Dari waktu ke waktu, sistem pertanian konvensional telah menimbulkan masalah lingkungan seperti pencemaran lingkungan, resistensi hama, dan ikut terbunuhnya musuh alami hama. Strategi lain untuk mengurangi dampak negatif yang timbul adalah melalui penerapan sistem pertanian sawah organik sebagai alternatif yang ramah lingkungan. Sistem pertanian organik dilakukan dengan menghilangkan penggunaan bahan kimia pada pupuk, pestisida maupun sarana budidaya tanaman lainnya. Tujuannya adalah mengurangi beban lingkungan dan menciptakan lingkungan ekosistem sawah yang sehat, alami dan tetap produktif. Dalam sistem pertanian sawah organik tidak menggunakan bahan kimia sintetik dalam aplikasi pupuk maupun pestisida. Pupuk yang digunakan adalah pupuk hayati (organik) berbahan pupuk kandang, pupuk kompos, dan pupuk hijau [1]. Munculnya kesadaran masyarakat akan bahaya kandungan zat kimia membuat masyarakat lebih selektif dalam memilih suatu produk terlebih untuk produk yang dikonsumsinya. Oleh karena itu, akhir-akhir ini banyak muncul berbagai produk pertanian organik di pasaran antara lain seperti sayur organik, buah organik, beras organik [2].

Sistem pertanian organik adalah sistem manajemen produksi yang holistik untuk meningkatkan dan mengembangkan kesehatan agroekosistem, termasuk keragaman hayati, siklus biologi, dan aktivitas biologi tanah [3]. Pertanian organik menekankan penerapan praktikpraktik manajemen yang lebih mengutamakan penggunaan input dari limbah kegiatan budidaya di lahan, dengan mempertimbangkan daya adaptasi terhadap keadaan/kondisi setempat. Jika memungkinkan hal tersebut dapat dicapai dengan penggunaan budaya, metode biologi dan mekanik, yang tidak menggunakan bahan sintesis untuk memenuhi kebutuhan khusus dalam sistem [4]. Di kalangan praktisi, ilmuwan, dan petani istilah produk organik marak digunakan, mulai dari makanan organik, seperti sayur organik, beras organik, buah-buahan bahkan sampai ayam atau sapi organik [5]. Isu ketahanan pangan belakangan ini menjadi isu yang sangat strategis karena berkaitan dengan kecukupan gizi masyarakat. Kebijakan pemerintah dalam pembangunan ketahanan pangan di Indonesia mensyaratkan tiga hal yang harus terpenuhi yaitu jumlahnya cukup, mutunya baik dan dapat dijangkau [6].

Dalam praktiknya, pertanian organik dilakukan dengan cara, antara lain: (1) Menghindari penggunaan benih/bibit hasil rekayasa genetika (GMO = genetically modified organism), (2) Menghindari penggunaan pestisida kimia sintetis, (3) Menghindari penggunaan zat pengatur tumbuh (growth regulator) dan pupuk kimia sintetis, dan (4) Menghindari penggunaan hormon tumbuh dan bahan aditif sintetis dalam makanan ternak.

Sejumlah keuntungan yang dapat dipetik dari pengembangan pertanian organik antara lain menghasilkan makanan yang cukup, aman dan bergizi sehingga meningkatkan kesehatan masyarakat. Data menunjukkan bahwa praktik pertanian organik mampu meningkatkan hasil sayuran hingga $75 \%$ dibanding pertanian konvensional. Di samping itu, produk pertanian 
organik juga mempunyai kandungan vitamin $\mathrm{C}$, kalium, dan beta karoten yang lebih tinggi. Petani akan terhindar dari paparan (exposure) polusi yang diakibatkan oleh digunakannya bahan kimia sintetik dalam produksi pertanian sehingga menciptakan lingkungan kerja yang aman dan sehat bagi petani. Terbangunnya kesadaran mengenai arti penting pertanian organik merupakan fondasi bagi keberlangsungan usaha tani dan gerakan pertanian organik. Menurunnya kesuburan tanah dan produktivitas lahan akibat penggunaan bahan-bahan kimiawi secara terus menerus telah membuka kesadaran sebagian petani untuk beralih ke pertanian organik sebagai upaya untuk merevitalisasi lahan, meningkatkan produktivitas dan menghasilkan produk pangan yang lebih sehat. Peralihan ke pertanian organik memerlukan pola pikir yang baru, terutama terkait dengan kompleksitas penerapan pertanian organik dibandingkan pertanian konvensional [7].

Salah satu yang dapat dengan mudah dibudidayakan dalam pertanian organik adalah sayuran. Sayuran merupakan jenis makanan penting bagi manusia untuk menjaga kesehatan. Sayuran hijau seperti sawi, kangkung dan bayam, memiliki beragam manfaat kesehatan. Kandungan zat gizi alami dalam sayuran hijau sangat banyak. Selain kaya dengan vitamin A dan C, sayuran hijau juga mengandung berbagai unsur mineral seperti zat kapur, zat besi, magnesium, dan fosfor [8]. Pertanian organik semakin berkembang karena didukung oleh gaya hidup sehat dan kembali ke alam (back to nature) telah menjadi tren baru masyarakat perkotaan. Dengan semakin positifnya persepsi masyarakat terhadap makan organik akan meningkatkan niat beli masyarakat. Menuut [9] persepsi konsumen memiliki hubungan positif terhadap sikap untuk membeli. Sikap untuk membeli juga berpengaruh positif terhadap niat beli makanan organik. Sedangkan hasil penelitian [10] persepsi yang baik terhadap produk makanan organik ditinjau dari atribut kesehatan, kualitas, harga, ramah lingkungan, dan keamanan makanan.

Sejalan dengan program pemerintah GO ORGANIK 2010 untuk memberdayakan petani organik dan tergerak dari rasa keprihatinan melihat kondisi tanah pertanian yang sakit, Gubug Lazaris termotivasi untuk dapat membuat sesuatu yang dirasakan masyarakat terutama dalam penanggulangan permasalahan di bidang pertanian. Gubug Lazaris diresmikan pada tanggal 27 Agustus 2010 di Desa Sambirejo, Kecamatan Pare, Kabupaten Kediri. Gubug Lazaris ini dikelola oleh romo-romo kongregasi CM.

Visi Gubug Lazaris yakni berpartisipasi aktif di tengah masyarakat pedesaan untuk mengembangkan pertanian organik yang sehat dan ramah lingkungan. Adapun misinya yaitu: (1) Sebagai sarana pembelajaran pertanian organik (untuk petani kecil, warga masyarakat di sekitar, maupun institusi lain yang berminat dengan pertanian organik), (2) Sebagai sarana pendidikan (diskusi) pertanian organik, (3) Sebagai sarana kerja nyata dalam hal pertanian organik, (4) Sebagai sarana informasi teknologi baru pertanian organik, dan (5) Sebagai sarana penyediaan hasil pertanian organik yang sehat dan ramah lingkungan.

Kegiatan-kegiatan yang sudah, sedang, dan akan dilaksanakan di Gubug Lazaris dalam membudidayakan pertanian organik antara lain: (1) Menanam padi dengan teknologi SRI (System Rice of Intensification) dan sayur organik, (2) Membuat Mikro Organisme Lokal (MOL) sebagai pengganti EM4 atau yang disebut EM Lestari, (3) Membuat pestisida nabati dengan memanfaatkan tanaman yang ada di lingkungan sekitar, dan (4) Membuat pupuk organik kascing (vermikompos) dengan menggunakan bahan baku limbah sapi (kotoran sapi) yang diproses dengan media cacing.

Tujuan Gubug Lazaris adalah mengembangkan pertanian organik dan melakukan pendidikan kepada masyarakat sekitarnya. Namun tujuan tersebut belum dapat tercapai dengan maksimal sebab keinginan masyarakat sekitar untuk menanam pertanian organik masih sangat rendah.

Tantangan yang dihadapi dalam mengembangkan pertanian organik adalah produktivitas pertanian organik lebih rendah, sehingga jika tidak ada insentif harga untuk produk organik maka petani tidak akan tertarik berusaha tani pertanian organik. Hambatan lainnya adalah sikap petani selama ini terlena oleh cara pertanian yang relatif serba cepat, mudah, kebutuhan relatif lebih sedikit sehingga menjadi tantangan untuk dapat merobah 
kembali menjadi petani yang tekun, sabar dan mau bekerja keras. Seperti yang dapat dilihat pada visi dan misi Gubug Lazaris ialah memberikan edukasi kepada masyarakat sekitar tentang pertanian organik. Sampai saat, ini visi dan misi tersebut belum bisa tercapai sesuai dengan yang diharapkan. Kendala yang dihadapi untuk mencapai visi misi tersebut antara lain: (1) Terbatasnya sumber daya personalia, waktu dan dana dalam memberikan pelatihan kepada masyarakat sekitar, (2) Kurangnya antusiasme penduduk sekitar dalam mempelajari atau mengonsumsi makanan organik, (3) Relatif mahalnya harga makanan organik dibandingkan dengan makanan anorganik, dan (4) Kurangnya pemahaman masyarakat bahwa budidaya tanaman organik dapat menjadi salah satu sumber penghasilan keluarga.

\section{Metode Pelaksanaan}

Pelatihan ini dilaksanakan bagi masyarakat dalam bentuk Pengabdian Kepada Masyarakat dengan Judul "Sosialisasi dan Pelatihan Pangan Organik bagi Masyarakat Desa Sambirejo Kecamatan Pare Kabupaten Kediri Jawa Timur". Peserta sebanyak 50 orang yang terdiri dari petani, pegawai, ibu pengurus rumah serta pelajar dan mahasiswa. Dalam melaksanakan kegiatan ini langkah yag dilaksanakan dapat dilihat pada Gambar 1.

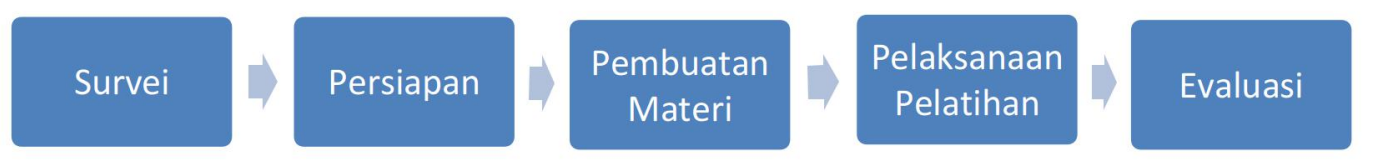

Gambar 1. Tahapan Pelaksanaan Pelatihan

Pada tahap survei, dilakukan identifikasi kebutuhan dan permasalahan yang dihadapi oleh mitra. Persiapan dilakukan untuk mengumpulkan materi yang dibutuhkan, bahan yang diperlukan, pendaftaran peserta serta persiapan tempat pelaksanaan sosialisasi dan pelatihan. Materi pelatihan disiapkan agar dapat dengan mudah dipahami oleh peserta pelatihan. Pelatihan dilaksanakan selama 1 hari dengan peserta sebanyak 50 orang. Pada akhir pelatihan dilakukan penyebaran senerai untuk evaluasi pelaksanaan pelatihan.

Materi pelatihan terdiri dari dua bagian, yaitu Konsep Pangan dan Tanaman Organik serta Penghitungan Biaya, Harga, dan Strategi Marketing Tanaman Organik. Di akhir pelatihan, peserta diberikan bibit tanaman, polibag, dan pupuk organik. Peserta diminta untuk menanam tanaman secara organik di rumah masing-masing.

\section{Hasil dan Pembahasan}

Sosialisasi dan Pelatihan Pangan Organik sangat diminati oleh masyarakat. Hal ini dapat dilihat dengan antusiasnya para peserta untuk mendaftar. Namun karena kapasitas ruangan dibatasi, banyak pendaftar yang terpaksa ditolak. Pembatasan ini dilakukan untuk menjaga protokol kesehatan karena wabah COVID-19. Pelaksanaan pelatihan dapat dilihat pada Gambar 2. Sedangkan proses diskusi dan evaluasi pelatihan dapat diihat pada Gambar 3.

Materi pelatihan tentang Konsep Pangan dan Tanaman Organik dapat diringkas menjadi: (1) Pertanian organik merupakan gerakan menentang arus yang sangat deras berupa kapitalisasi dunia pertanian oleh perusahaan obat, pupuk, dan benih kimia; (2) Perusahaan raksasa dunia itu berusaha mencengkeram dengan dominasi mereka soal benih, obat-obatan, dan pupuk. Petani diajak secara terus menerus menggunakan produk-produk mereka yang saling berkaitan; (3) Dalam pertanian konvensional menggunakan bibit unggul hasil rekayasa, pupuk kimia untuk menyuburkan tanaman, dan obat kimia untuk menyehatkan tanaman dan buahnya. Namun hal tersebut tidak hanya membunuh gulma, tetapi juga mematikan unsur-unsur hara yang ada di tanah; (4) Pertanian Organik pertama-tama adalah mengolah tanah agar tanah menjadi sehat 
tanpa menggunakan pupuk dan obat-obatan yang bersifat kimiawi; (5) Produk atau hasil ditujukan untuk melestarikan benih; dan (6) Pertanian organik pasti mendukung konsep ekologis atau pelestarian alam: tanahnya sehat, tanamannya sehat, kalau kita konsumsi tubuh kita juga sehat sehingga kita ikut menjaga kelestarian atau keutuhan ciptaan.

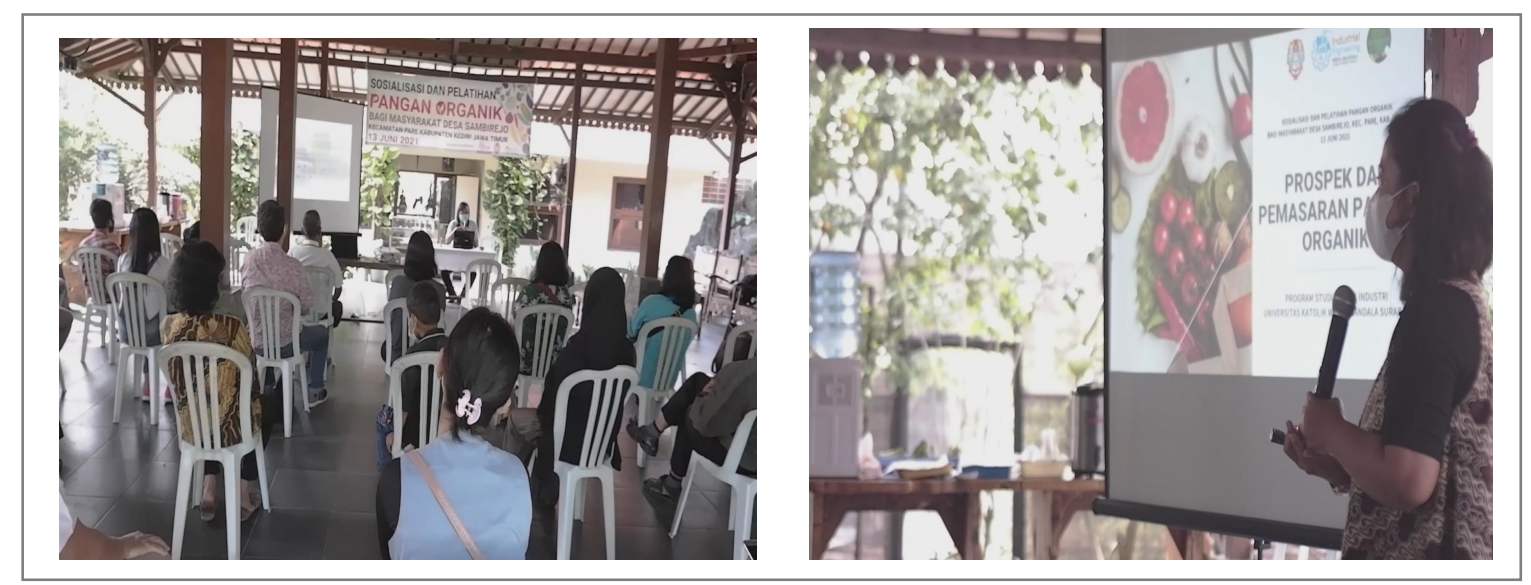

Gambar 2. Pelaksanaan Pelatihan

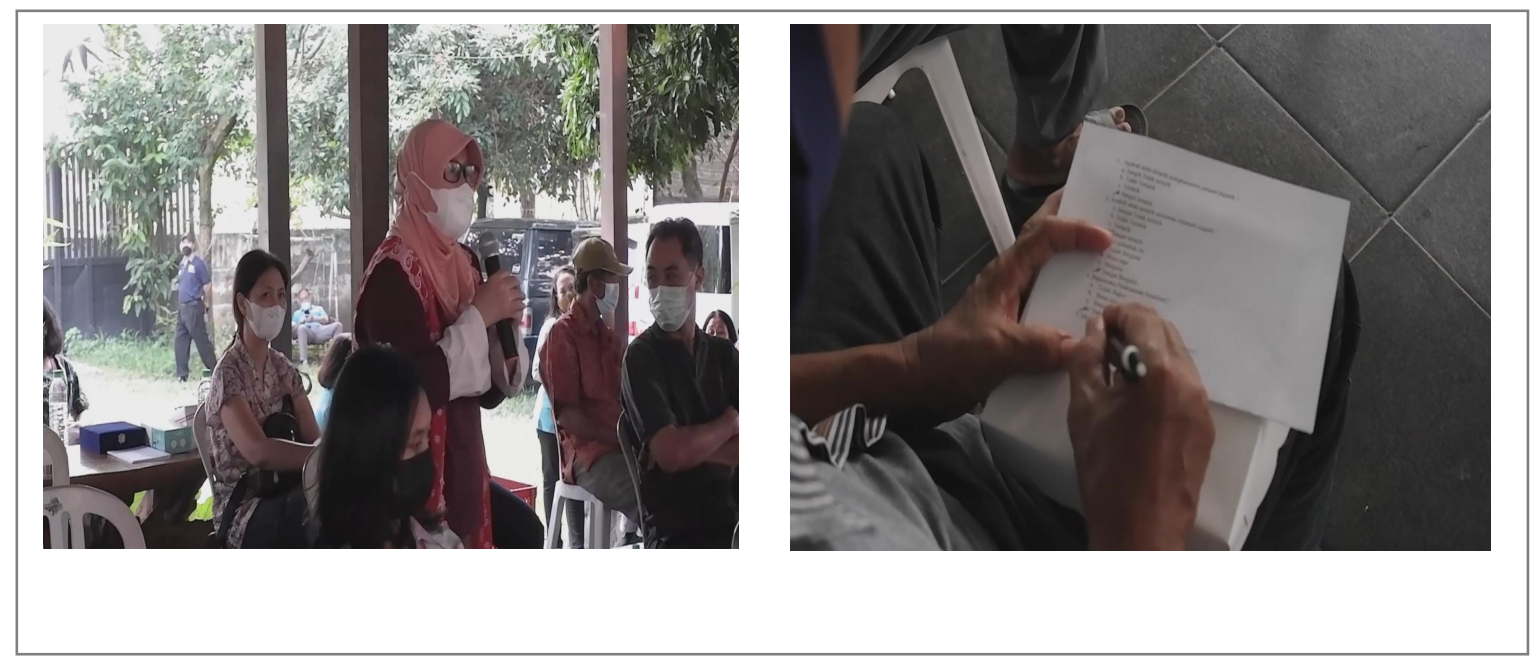

Gambar 3. Diskusi dan Evaluasi Kegiatan

Sedangkan ringkasan materi tentang Penghitungan Biaya dan Harga serta Strategi Marketing Tanaman Organik yaitu: (1) Permintaan pangan organik semakin meningkat dan sangat kompetitif di pasar internasional; (2) Beberapa alasan masyarakat mengonsumsi pangan organik adalah makanan lebih sehat, cita rasa lebih baik, kandungan gizi lebih beragam, ramah lingkungan serta solidaritas terhadap petani organik; (3) Pemasaran pangan organik bisa melalui beberapa saluran pemasaran yaitu pasar tradisional, pasar modern, secara langsung dan pasar online; (4) Sedangkan tantangan dalam mengembangkan pangan organik antara lain: standardisasi pangan organik, persepsi masyarakat bahwa harga pangan organik mahal, kemasan yang harus menarik, penanganan setelah panen serta pengetahuan masyarakat tentang pangan orgnanik; (5) Pengemasan harus dilakukan dengan pertimbangan antara lain menjaga kerbersihan dan kesegaran pangan organik, menarik serta mudah untuk menyimpan.

Pada akhir pelatihan, dilakukan penyebaran senerai untuk mengetahui respon dari peserta. Pertanyaan yang pertama adalah untuk mengetahui ketertarikan peserta mengonsumsi pangan organik. Hasil senerai menunjukkan bahwa $57,5 \%$ peserta sangat tertarik mengonsumsi pangan organik dan $42,5 \%$ tertarik seperti dapat dilihat pada Gambar 4 . Sedangkan pertanyaan 
kedua untuk mengetahui ketertarikan peserta menanam tanaman organik. Hasil senerai menunjukkan bahwa $42,5 \%$ peserta tertarik menanam tanaman organik dan sisanya tertarik, seperti terlihat pada Gambar 5.

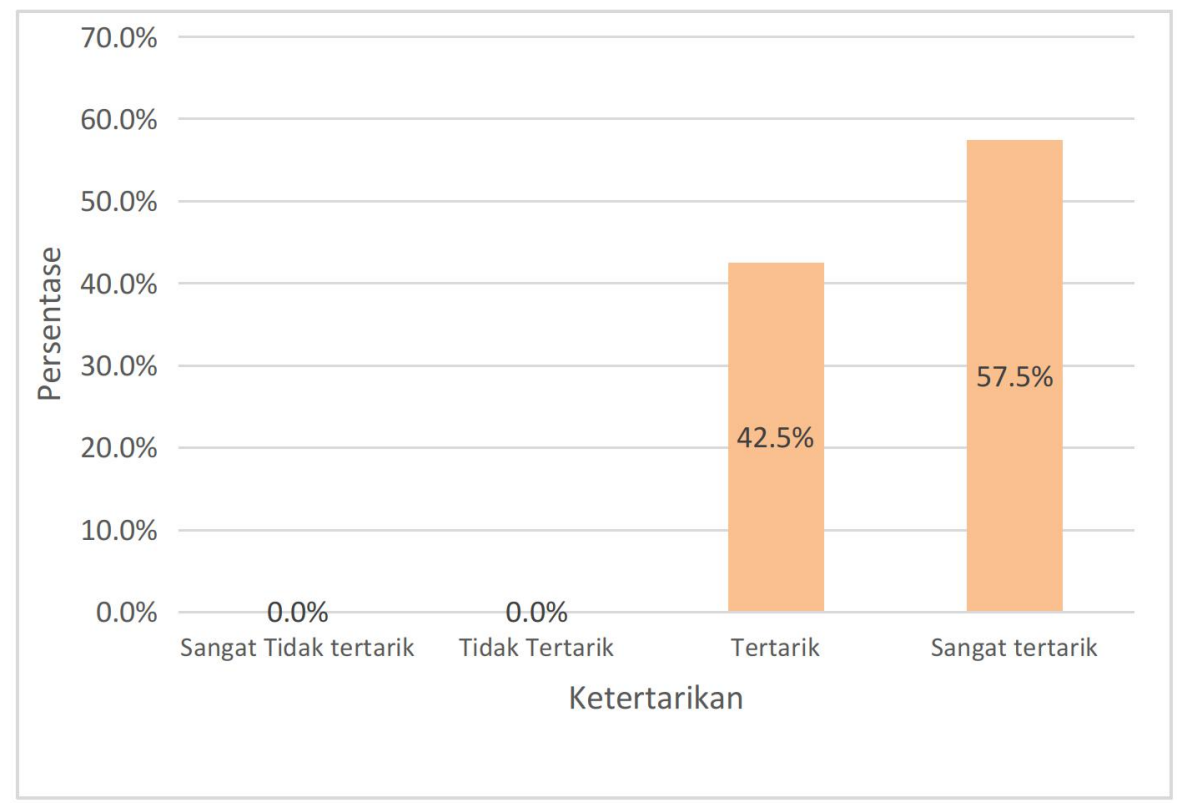

Gambar 4. Grafik Persentase Peserta Tertarik Mengkonsumi Pangan Organik

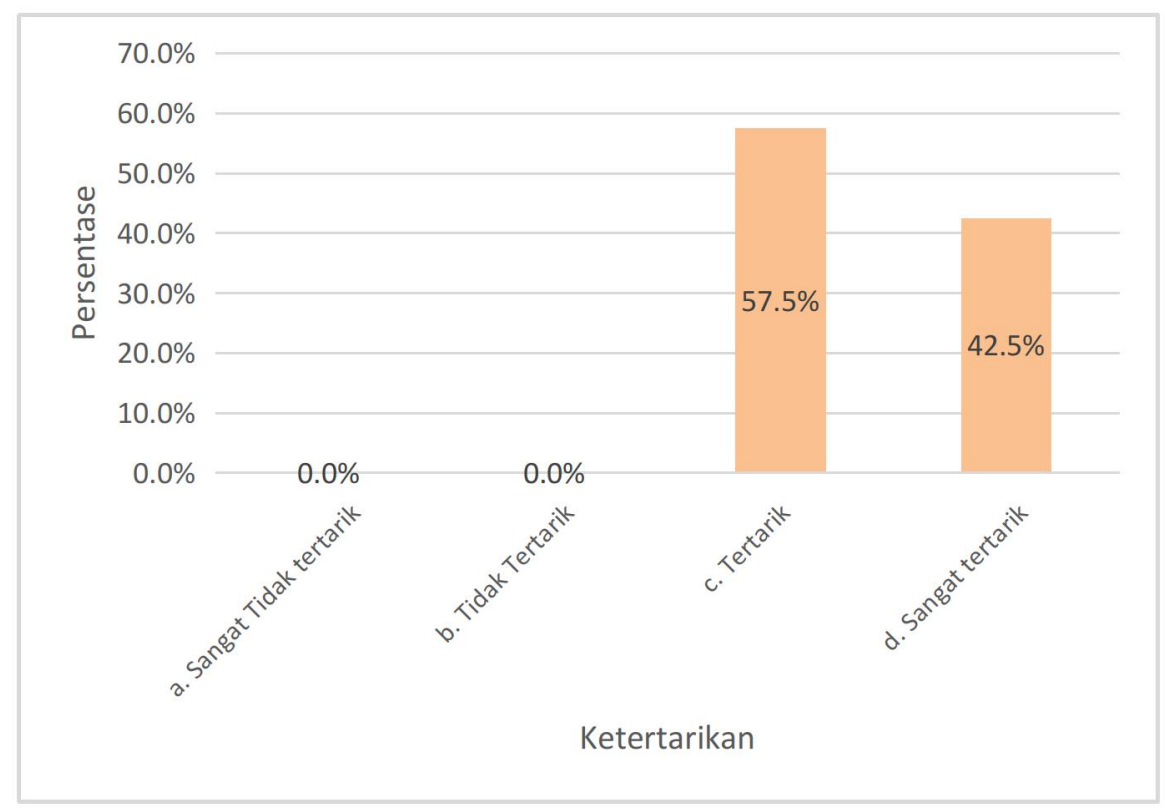

Gambar 5. Grafik Persentase Peserta Tertarik Menanam Tanaman Organik

\section{Kesimpulan}

Kesimpulan pelaksanaan Sosialisasi dan Pelatihan Pangan Organik antara lain: (1) Evaluasi kegiatan ini menunjukkan bahwa peserta mempunyai ketertarikan untuk mengonsumsi dan menanam pangan organik, dan (2) Mengembangkan pangan organik menghadapi banyak tantangan, terutama penyadaran masyarakat akan pentingnya hidup sehat dan kelestarian lingkungan. Selain itu, hambatan yang lain ialah harga pangan organik yang relatif lebih mahal. 


\section{Ucapan Terima Kasih}

Penulis mengucapkan terima kasih kepada Universitas Katolik Widya Mandala Surabaya yang telah membiayai kegiatan Pengabdian Masyarakat "Sosialisasi dan Pelatihan Pangan Organik bagi Masyarakat Desa Sambirejo Kecamatan Pare Kabupaten Kediri Jawa Timur”.

\section{Daftar Pustaka}

[1] M. Hadi, R. H. Soesilohadi, F. Wagiman, and Y. Rahayuningsih, "PERTANIAN ORGANIK SUATU ALTERNATIF PENGELOLAAN EKOSISTEM SAWAH YANG SEHAT, ALAMI DAN RAMAH LINGKUNGAN,” Bul. Anat. Dan Fisiol., vol. XXII, no. 1, pp. 72-77, 2014.

[2] M. Khorniawati, "Produk Pertanian Organik Di Indonesia: Tinjauan Atas Preferensi Konsumen Indonesia Terhadap Produk Pertanian Organik Lokal,” J. Studi Manaj., vol. 8, no. 2, pp. 171-182, 2014.

[3] H. Mayrowani, "Pengembangan Pertanian Organik Di Indonesia The Development Of Organic Agriculture In Indonesia," Forum Penelit. Agro Ekon., vol. 30, no. 2, pp. 91-108, 2012.

[4] Badan Standar Nasional Indonesia, SNI Sistem Pertanian Organik. Jakarta: Badan Standardisasi Nasional, 2016.

[5] R. Eviyati, "Pertanian organik dalam berbagai perspektif," Agrijati J. Ilm. Ilmu-Ilmu Pertan., vol. 4, no. 1, pp. 18-21, 2017.

[6] A. Hamzah and S. U. Lestari, "Rumah Pangan Lestari Sebagai Solusi Peningkatan Pendapatan Keluarga,” J. Akses Pengabdi. Indones., vol. 1, no. 1, pp. 65-72, 2016, doi: 10.29303/jpmpi.v3i2.585.

[7] Nurcahyaningtyas Subandi, “Aspek Ekonomi Pertanian Organik : Hambatan , Tantangan dan Strategi Pengembangan di Pulau Jawa," Yogyakarta, 2018.

[8] D. Iriyani and P. Nugrahani, "Komparasi Nilai Gizi Sayuran Organik Dan Non Organik Pada Budidaya Pertanian Perkotaan Di Surabaya,” J. Mat. Sains Dan Teknol., vol. 18, no. 1, pp. 36-43, 2017, doi: 10.33830/jmst.v18i1.173.2017.

[9] S. F. Eles and S. O. Sihombing, "Determinan Niat Beli Makanan Organik: Sikap untuk Membeli sebagai Variabel Mediasi,” MIX J. Ilm. Manaj., vol. VI, no. 3, pp. 313-332, 2016.

[10] D. Waskito, M. Z. Ananto, and A. R. S. P, "PERSEPSI KONSUMEN TERHADAP MAKANAN ORGANIK DI YOGYAKARTA,” Pelita, vol. IX, no. 1, pp. 36-48, 2014. 


\section{Afiliasi:}

Ig. Jaka Mulyana*, Lusia Permata Sari Hartanti, Dian Trihastuti, Ivan Gunawan Program Studi Teknik Industri Universitas Katolik Widya Mandala Surabaya Jl. Kalijudan 37 Surabaya

Email: jmulyono@ukwms.ac.id* 